\title{
MAQĀṢID AL-SHARIAH IN THE CONTEMPORARY ISLAMIC LEGAL DISCOURSE: PERSPECTIVE OF JASSER AUDA
}

\author{
ZAPRULKHAN * \\ Institut Agama Islam Negeri Syaikh Abdurrabman Siddik \\ Bangka Belitung
}

\section{Abstract}

Nowadays, Muslims are facing various contemporary problems related to the discourse of fiqh or Islamic law. In this case, the old tradition of Islamic jurisprudence is no longer sufficient to answer those problems due to the changes in the context of space, time, culture, and contemporary sciences. Any effort to renew the aspect of methodology must be done in the field of ușul al-fiqh not only in Islamic jurisprudence. This is the reason that methodological reconstruction is needed in order to make it is able to accommodate the various problems that are disturbing Muslims today. One of Muslim scholars who tried to reconstruct at the level of the methodology of maqāsid al-shariah is Jasser Auda. For the purpose of reconstructing maqāșid al-shariah fundamentally, Auda uses a philosophical approach that is multidisciplinary as well as open with various other relevant disciplines as a methodological framework for reforming the study of ușul al-fiqh and Islamic law. Applying philosophical and historical approach this study found that Auda reconstructs maqāșid al-shariah by offering six features: cognitive nature, wholeness, openness, interrelated hierarchy, multidimensionality, and purposefulness. Furthermore, Auda gives contribution to the development of Islamic law and human rights. This paper will explore reconstruction as well as the contribution of maqāsid al-shariah promoted by Auda through the approach of the philosophy of the system.

\footnotetext{
* Corresponding author: Jl. Raya Petaling, Mendo Barat, Bangka Belitung, Indonesia 33173. E-mail: zaprulkhan_zahra@yahoo.co.id.
} 
Saat ini, umat Islam menghadapi berbagai masalah kontemporer yang sangat kompleks terkait dengan wacana fikih atau bukum Islam. Dalam hal ini, tradisi lama yurisprudensi Islam tidak lagi cukup untuk menjawab masalah kontemporer yang kompleks karena perubahan dalam konteks ruang, waktu, budaya, dan sains kontemporer. Upaya untuk memperbarui harus dilakukan pada metodologi dalam ușul al-fiqh tidak hanya pada tingkat yurisprudensi. Di sinilah rekonstruksi diperlukan pada tingkat metodologis sehingga mampu mengakomodasi berbagai masalah yang mengganggu umat Islam saat ini. Seorang ilmuwan Muslim yang berusaha merekonstruksi pada tingkat metodologi maqāṣid al-shariah adalah Jasser Auda. Dalam kerangka rekonstruksi maqāṣid Islam, Auda menggunakan pendekatan multidisiplin-filosofis serta terbu$k$ a dengan berbagai disiplin ilmu lain yang relevan sebagai kerangka kerja metodologi untuk mereformasi bidang studi ușul al-fiqh atau ranah hukum Islam. Penelitian ini menggunakan pendekatan filosofis dan historis. Hasilnya ditemukan bahwa Auda merekonstruksi maqāșid al-shariah dengan menawarkan enam fitur: sifat kognitif, keutuhan, keterbukaan, hierarki yang saling terkait, multidimensi, dan kebermaksudan. Lebih jauh, Auda memberikan kontribusi pada pengembangan hukum Islam dan Hak Asasi Manusia. Artikel ini akan mengeksplorasi rekonstruksi serta kontribusi maqāșid al-shariah yang dipromosikan oleh Auda melalui pendekatan filsafat dari sebuah sistem.

Keywords: Islamic jurisprudence; Islamic law; Jasser Auda; maqāṣid al-shariah; paradigm reconstruction; system approach.

\section{Introduction}

Today, Muslims are facing various contemporary problems. Unfortunately, the response often displayed is a defensive-apologetic attitude and counter-productive actions. As a result, the majority of the Muslims are more and more confined in alarming condition. They actually have conducted ijtihad but it is still limited to repeated reading (al-qirä'ah al-mutakarrirab). They 
are not really brave to carry out new ijtihad (al-qira'ah al-munti$j a h)$ as expected by Shaikh Amir Syakib Arsalan, Muhammad Abduh, Muhammad Iqbal, and others around almost a century ago.

Therefore, it is time to reform the paradigm and interpretation of Islamic teachings through understanding and interpreting Islamic law as its main target. What is meant here is the understanding and interpretation of Islamic law that is in line with the development of modern sciences. Furthermore, understanding Islamic law by considering the development of natural, social, and humanities sciences will have an impact on all aspects of human life including in the fields of education, state, and nation, as well as social life and human culture.

When talking about the discourse of figh and law in Islam, both of them are more frequently related to various contemporary problems of life of the people compared to the discourse of 'aqìdah and morality. Various scientific discussions in the form of emotional debate among ordinary people to academicians are more focusing on Islamic law as the main topic. Khiläfah (caliphate), human rights, gender mainstreaming, children's rights, environmental rights, political, social and cultural rights, religious freedom, relations between Muslims and non-Muslims in various parts of the world, economic development, scientific attitude and human resource development are some examples of the issues in fiqh that are becoming hot discourse among Muslims in Islamic countries, especially Muslim-minority countries in the West (Auda 2015, 9-10).

In this context, some Muslim scholars propose the formulation of maqāṣid al-shariah (objective of sharia) to answer the various problems that are currently disrupting the Muslims today (Riḍa 1406). With regards to the reconstruction of maqāṣid al-shariah, in fact, several Muslim scholars of the modern and 
contemporary era have emerged to criticize the weaknesses of the classical maqāṣid al-shariah and at the same time made a reconstruction over maqāṣid al-shariah (Al-Alwani 2001). Some of the Muslims scholars have formulated the basic rules of maqāṣid al-shariah and the examples of its application in solving the problems of fiqh (Ibn Ashūr 2006). However, their studies of maqāṣid al-shariah have not used a comprehensive methodological framework (Al-Alwani 2001).

That is why reconstruction is needed at the methodological level so that it is able to accommodate the various problems that are plaguing the Muslims today. One of the Muslim scientists who made a reconstruction at the level of the methodology of maqāṣid al-shariah was Jasser Auda. The reconstruction carried out by Auda started from his anxiety with various kinds of violence, criminal acts, and terrorism carried out in the name of Islamic law as claimed by several perpetrators.

For the purpose of conducting fundamental reconstruction of maqāsid al-shariah, Auda uses the approach of the philosophy of the system which is multidisciplinary and at the same time open to various other relevant disciplines as a methodological framework for reforming the field of study of ușul al-fiqh or Islamic law. Openness to a number of different concepts, theories, and disciplines is a necessity for a multidisciplinary system approach. Because without combining relevant ideas from other disciplines, the research in the basic theories of Islamic law would be confined within the boundaries of traditional literature and manuscripts, and the Islamic law will continue to become 'outdated' on a theoretical basis as well as in practical results. This paper will explore the reconstruction as well as the contribution of maqāṣid al-shariah promoted by Auda through the approach of the philosophy of the system. 
As far as the author's observations, there are no researchers who have seriously studied Jasser Auda's thoughts about his paradigm on reconstruction of the maqāsid al-shariah and its specific contribution. It must be admitted that indeed there have been a number of writings that highlight Jasser Auda's way of thinking, but generally only portray a small part of the aspect of his thinking that includes a glimpse of his works.

First, Mohammad Darwis in his article entitled Maqāṣid al-Shariah and the System Approach in Islamic Law in Jasser Auda's Perspective. In this article, Darwish described the approach of the system used by Jasser Auda in formulating maqāṣid al-shariah. Even though Darwish has portrayed globally the criticisms and the approach of the system of Jasser Auda, he has not explained yet the reconstruction of the paradigm of the maqāșid al-shariah that Jasser Auda has constructed comprehensively and also his contribution (Mu'ammar 2012, 385-424).

Second, another article was written by Musyarrofah and Chumaidah titled The Method of System Analysis in the Philosophy of Islamic Law: A Study of Jasser Auda's Thought. As the title suggests, Musyarrofah and Chumaidah also outlined a system analysis approach toward Islamic law introduced by Jasser Auda. In this article, they explore the archeological system approach which must maintain the style of goal orientation, openness, cooperation between subsystems, hierarchy, and the balance between decomposition and integration. The big ideas about the system approach were developed by Jasser Auda based on the views of the experts in the field of systemic approaches in various aspects.

Then they both also explained the system approach of Jasser Auda that proposed six characteristics of contemporary maqāșid al-shariah. Nevertheless, Musyarrofah and Chumaidah have not discussed comprehensively and systematically about the reconstruction and contribution of the maqāṣid al-shariah paradigm initiated by Jasser Auda (Mu'ammar 2012). 
Third, an article written by Amin Abdullah. In his article, Amin Abdullah compares between Abdullah Saaed's and Jasser Auda's thought in responding to globalization. Like the two previous studies, Amin Abdullah only elaborates the reconstruction of maqāṣid al-shariah initiated by Jasser Auda. He does not explore the contribution made by Jasser Auda (Abdullah 2012, 315-368). Therefore, this study is still significant to be explored further.

\section{The Construction of Classical Maqāṣid al-Shariah}

The Meaning of Maqāșid al-Shariah and its Classification

The word 'maqāṣid' has several meanings, i.e. the goals, objectives, and final objectives of Islamic law (Auda 2013, 6). While the word 'shari'ah' is a derivation of the word shara'a - yashra'u - shir'an/sharī'atan, a verb consisting of three letters that is shin, ra', and 'ain. According to Ibn Faris, the basic meaning of the word is 'source/spring', whereas according to al-Asfahani, the word means al-tariqah al-wadihah 'clear path' as in the expression shara'tu labu thariqatan' II explain the path for him' (Sahabuddin 2007, 946).

Literally, sharia also means a path to a water source, which is clear to be followed and must be lived by believers to get guidance in this world and salvation in the hereafter. In general, sharia refers to commands, prohibitions, guidelines, and principles from God for human behavior in this world and its salvation in the hereafter. These and other sacred guides allow humans to leave the bad impulse, namely unlimited desires and tendencies to do evil; guiding humans toward virtue and truth, and making them honorable and believed to be the vicegerent of Allah swt. on earth (Kamali 2008, 19).

Whereas maqāṣid al-shariah is expressed by the scholars of Islamic law in various meanings, ranging from Imam Bannani, Asnawi, Imam Ghazali, Amidi Ibn al-Hajib, to Shațibi and Ibn Ashūr. Imam Shațibi describes maqāṣid by connecting to three 
categories namely darūriyyāt (primary needs), hājiyyāt (secondary needs), and tabssiniyyāt (tertiary needs). After Shațibi, the maqāșid al-shariah discourse met a deadlock for six centuries and until the emergence of Tahir Ibn Ashūr which made maqāṣid al-shariah an independent scientific discipline. According to Ibn Ashūr, all sharia laws must contain wisdom benefits, and advantages, as well as the general purpose of the Sharia to maintain the order of the people and the continuity of their lives (Mawardi 2010, 180-182).

In his work titled Maqāșid al-Shariah al-Islamiyyah, Ibn Ashūr provides the definition of maqāṣid al-shariah as a number of objectives and wisdom that are used as a basis for shari'a in all the provisions of religious law or the majority. These objectives are not supposed to be applied specifically to one product of sharia laws. The definition of Ibn Ashūr above refers to the meaning of maqāșid al-shariah globally. However, Ibn Ashūr also gives a specific meaning of the maqāșid al-shariah as a variety of efforts pursued by the Shari'a in order to realize the benefits for human beings for their actions specifically. The meaning of the definition is specific which includes the life of a happy household, away from conflict of the domestic life, the divorce, and others (Subhan 2013, 1-2).

Regardless of the different words used in defining maqāșid al-shariah, the ulama of ușūl al-fiqh agreed that maqāṣid al-shariah is the ultimate goal that must be realized by applying the sharia, both general and specific maqāsid that is related to the life of mankind. Based on various meanings of maqāșid al-shariah, the ulama divided maqāșid al-shariah into various categories. Abu Ishaq al-Shațibi, as the founder of maqāșid al-shariah classified maqāșid al-shariah into three categories: darūriyyāt (essential), hājiyyāt (complementary), and tahsiniyyāt (tertiary) (Mawardi 2010). 
Maqāșid al-Shariah Classification

First, darūriyyāt consists of everything that is fundamental and essential to maintain the interests of the world and the hereafter. Darüriyyāt is anything if it is not available will cause damage to life. This is related to four things: worship, 'ádat, $m u$ 'àmalat, and jināyat. Worship refers to defending religion; for example, maintaining the faith, saying two sentences of creed, prayer, almsgiving, fasting, pilgrimage, and the like. 'Ādat refers to the protection of life and mind, for example, food, drink, clothes, and residence. $M u^{\prime}$ àmalat refers to protection of offspring and property, as well as protection against reason. While jināyat refers to al-amr bi al-ma'rūf and al-nahy' 'an al-munkar. Furthermore, the protection of al-darüriyyāt al-khams includes five things, i.e. the protection of religion, soul, mind, lineage, and wealth.

Second, häjiyyāt is understood as everything which is very important for the protection of human life but does not reach the emergency level. At this level, if the rights are not fulfilled, then some of these rights can still be carried out even though they do not achieve the ideal and are very likely weak. The complementary category also includes parts of the field of worship, customs or habits, mu'àmalat, and includes the field of jināyat. In the field of worship, for example, is exemption for sick people not to fast in the month of Ramadan. Adat is like being allowed to hunt and consume halal food. Muamalat is like buying and selling, investing, and the like. Jināyat imposes a fine for a murderer who has reason. (Marcoes 2018, 12-13).

Third, tabsiniyyāt is the things that are not really important for the protection of rights. But if fulfilled, tạsiniyyāt will improve the implementation of other rights. Like darūriyyāt, häjiyyāt, and tabsiniyyāt also refers to these four things. In the matter of worship such as removing uncleanness, covering the genitals, doing a lot of nawāfil (recommended prayers) to get 
closer to God, alms, and the like. Adat is like keeping courtesy when eating and drinking, keeping away from unclean food and drinks. Mu'āmalat is like a prohibition on selling unclean goods, a prohibition against women to become imam of prayer, and forbidding them to marry themselves without a guardian. Jinayat is like a prohibition for free people to kill the slaves, women, small children, and priests during the war (Marcoes 2018; Busyro 2017).

\section{Reconstruction of Maqāṣid al-Shariah}

The Approach to Philosophy and the Features of Maqāsid al-Shariah System

In his reconstruction, Jasser Auda used the approach of the philosophy of the system. In this regards, the first step taken by Jasser Auda is to elaborate on the meaning of the system in general and then identify the various features used in the analysis of the system. According to him, the philosophical approach of the system views the world and the functions of nature and all its components in the context of a holistic system that is composed of an infinite number of sub-systems which have the nature of interaction, openness, hierarchy, and purpose (Auda 2015, 61).

Therefore, with the philosophy of the system, the concept of 'intentions' (maqāsid) with all its teleological shadows has returned to philosophical and scientific discourse. The philosophy of the Islamic system (Islamic system philosophy) is an idea that Auda wants to put forward. The new proposed Islamic philosophy can be beneficial from the criticism of the philosophy of the system towards modernism and post-modernism, to criticize any version of Islamic-based modernism (Auda 2015, 64).

In the view of Auda, the system approach is a holistic approach by looking at each entity as a single system consisting of a number of sub-systems. In the system approach, there are various system features that influence each other among the compo- 
nents of the sub-system, and can interact with each other with the environment outside the system (Auda 2015, 64-65). From here, Auda could identify a variety of features contained in the philosophy of the system more comprehensively than other system theorists, such as Bertalanffy, Churchman, Bowler, Waever, Ackoff, and Skyttner (Auda 2015, 72-85).

For this reason, Auda proposed a series of new system features that could be used in a systematic analysis of maqāṣid al-shariah which included the following six features: cognitive nature of the system, wholeness, openness, interrelated hierarchy, multi-dimensionality, and purposefulness (Auda 2015, 86).

\section{Towards All Cognition Validation}

In the reconstruction of the philosophy of the system, the first thing that Jasser Auda put forwards is to understand the cognitive natures of human knowledge. With this cognitive nature, Auda wants to distinguish between human's profane knowledge and fundamental religious texts that are sacred. In other words, all the results of the ulama's understanding of the sacred religious texts (al-Quran and Hadith) in the form of fiqh are purely as the products of interpretations of the ulama. All products of interpretation and the results of ijtihad of the ulama are not divine.

The problem is that the results of ijtihad of the ulama are often regarded as divine knowledge, even though there are different opinions regarding the definition and validity of the methods of ijtihad. The main example, in this case, is consensus $\left(i j m \bar{a}^{-}\right)$. Apart from the differences of opinion about the definition of ijma', the Muslims in the past as well as in the present still consider it as a valid postulate like the nash, a proposition constructed by the sharia Maker.

In the literature of traditional fiqh, ijma' is not rarely claimed in the laws which clearly have differences of opinion, in order to 
support one opinion or another opinion. Ibn Taimiyah, for example, examined Ibn Hazm's work, Marātib al-Ijma' (the level of ijma') in his work, Naqd Marātib al-Ijma' (Criticism of the Levels of Ijma'). Ibn Taimiyah mentions many examples of inaccurate ijma' made by Ibn Hazm regarding a number of ijtihad issues, even though there are many differences of opinion. (Auda 2015, 72-85).

With this argument, Auda argues that ijma' is not a source of law, but merely a mechanism of consultation, or using the terminology of the system, it is multi-participatory decision making. However, ijma' is used by some contemporary scholars to monopolize fatwas and limit them to certain central elites, referring to the use of the postmodernist concept. Auda also agreed with the modernists who stated that the principles of ijma' at this time are used as a mechanism for making collective fatwas, especially with the presence of modern technology and instant communication throughout the world. Furthermore, he also agreed with other proposals that developed ijma' to become a means of public participation in state affairs.

On the other hand, some of the jurists regard that qiyas (analogical reasoning) method is divinely approved. They state that making an analogy between the primary case and the secondary case is the analogy made by the sharia Maker itself. Therefore, even in the cases of ijtihad that are clearly containing faults, some people still judge themselves to speak in the name of God (Auda 2015, 253). Based on this reason, Auda proposed to separate the divine revelation from the interpretation of humans with cognitive nature.

Thus, the system approach to Islamic law will present a perspective that is flexible and very rich in expressing the meaning of the truth that has been explored by the ulama (Auda 2015, 254). In order to systematically be able to separate the Divine 
aspects from Islamic jurisprudence or cognition, Auda describes the scheme of the relationship between fiqh, sharia, 'urf, and $q a$ $n \bar{u} n$ in figure 1.

Figure 1

Relationship between fiqh, sharia, 'urf, and qanūn

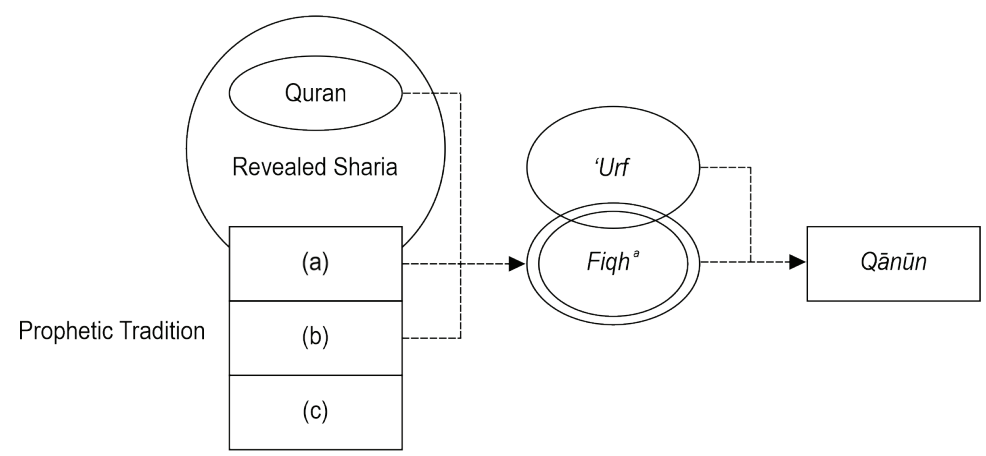

a Fiqh and a section of the prophetic tradition are shifted from being expressions of the 'revealed' to bein expressions of the 'buman cognition of the revealed' (Auda 2008b, 196).

\section{Towards Holism}

With holism features, Jasser Auda questions the uncertainty of individual postulate and the limitations of the concept of causality in both theology and law. The approach to law which is only based on one text in overcoming the problems without connecting with other related texts is a reductionist approach or atomistic approach. While the concept of causality discusses the principle of cause and effect in the deed of God both the deed that is related to creation ( $f^{\prime} l$ khalqiy) and the deed that is related to law (fil tashri'iy). Both the atomistic approach and the principle of causality in theology and law epistemologically have principal weaknesses.

Through the approach of philosophy of the system, Auda proposed a holism feature to overcome these problems. According to Auda, contemporary philosophical system affirms that synthetic and holistic tendencies are naturally fundamental. The 
philosophers of the system state that if we expand the notion of causation to encompass all causal networks around us, a complex sequence will be born, where something can happen not because of a single cause, but because of a complexity that has a common goal. This complexity is considered to be closer to the real structure of our world.

Auda proposed that the principle of holism, as explained in the philosophy of the system, could play a role in the proposal of contemporary reform, not only in Islamic law but also in the sciences of Kalam. Simply speaking, the proposition of creation should be based on the impossibility of an action without a purpose, rather than the impossibility of an action without a cause, as traditionally affirmed.

The principle of maintenance or guardianship should be based on the balance and comfort of humans in the earth's ecosystems and subsystems, rather than the classic arguments in the form of direct maintenance. Likewise, the proposition of God's existence (theorem of al-wujüd) should be based on a systematic and integrative design of the universe, as we know it today, rather than relying on the classical cosmological argument of First Cause, using the expression of Muhammad Abduh (Auda 2015, 260-262).

\section{Towards Openness and Self-Renewal}

In Jasser Auda's perspective, there are two mechanisms for openness and self-renewal in Islamic law in sequence. First, the renewal through cognitive culture. In this regard, it is to make legal changes by changing the world view or cognitive character of a faqih. One's worldview is usually related to one's own cognitive culture which is definitely related to the existence of the outside world. This is where the worldview of the faqih is related to 'urf in Islamic legal theory. When customs are taken into consideration, the goal is to be able to accept various forms 


\section{ZAPRULKHAN}

of customs outside Arabic culture which are very plural (Auda 2015, 263).

However, according to Auda, the practical implications of ' urf in fiqh itself are still limited. Many Islamic laws are still affected by Arabic customs of the first two or three centuries of the hijri including politics, geography, food, various economic sources, and social systems of the era, as a result of the world view developin at that time. There are so many examples of the dominance of Arabic customs over Islamic law, such as zakat fitrah at the end of Ramadan which is still determined based on the foods of the $7^{\text {th }}$ century such as dates, raisins, and wheat (Auda 2015, 264)

Figure 2

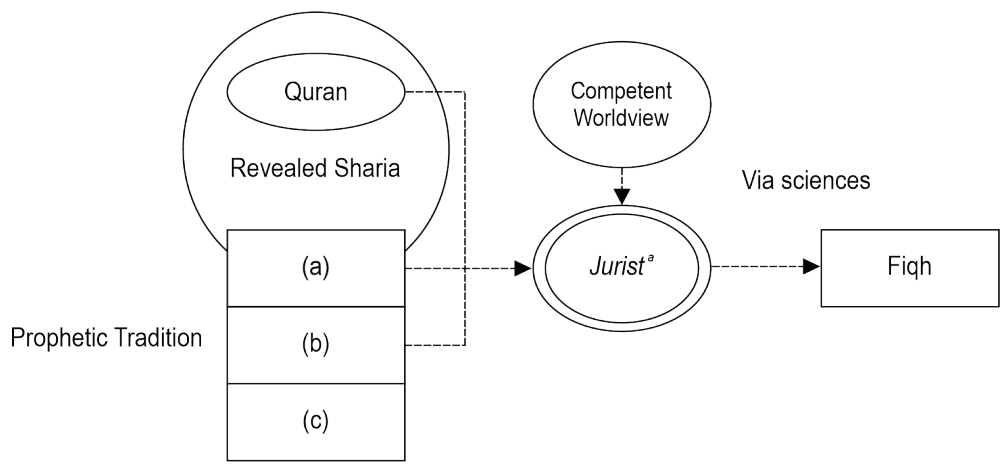

a The jurist's worldview is a prime factor in formulating fiqh (Auda 2008b, 2015, 266).

In his opinion, such thinking is againts the principle of al-maqāṣid that is the equality of human beings which is expressed in a number of texts (Auda 2015, 265). For this reason, Auda proposed the worldview of a faqih as an extension of the method of the customs in order to be able to accommodate various changes in the standard customs of classical Arabs (Auda 2015, 265). In this case, Auda shows the scheme which reflects the importance of the world view of a competent Jurist in figure 2. It illustrates how the worldview of a faqih determines the position taken in 
the Islamic legal system. This chart illustrates the centrality of the role of the faqih, which is the result of incorporating world views into the Islamic legal system. Al-Quran and Sunnah that is related to law are both sources and parts of the world view of the faqih. The other components of the worldview of the fäqih are combined with Al-Quran and Sunnah to produce fiqh. Nevertheless, the faqih must have a competent worldview based on a scientific basis. Because without a competent worldview, the faqih will not be able to make accurate decisions in fiqh (Auda 2015, 266-268).

Second, legal reform through philosophical openness. What is meant by Auda with philosophical openness is the openness of the faqih to the philosophical discourse. In this context, uṣul al-fiqh as part of the philosophy of Islamic law needs to adopt a philosophical approach in accordance with the development of human sciences which are always evolving (Auda 2015, 268269).

The attitude of openness shown by Ibn Rushd to various philosophical thoughts from where they came from can be adopted. For this reason, Jasser Auda proposed the philosophical openness that must be possessed by the faqih when conducts a reform to Islamic law, one of which is to get back the spirit of Ibn Rushd in using philosophical discourse creatively. "In order that the Islamic legal system maintains its own renewal, we need to adopt Averroes's openness to all philosophical investigations and expand this openness to the theory of ușul al-fiqh itself”, writes Jasser Auda (Auda 2015, 274-275).

Interrelated Hierarchy of the System of Islamic Law

Hierarchical entity analysis is a general approach between systematic methods and decomposition. Here Auda refers to the theory of 'categorization' in the sciences of cognition, as an attempt to describe the universal classification strategy that fits 
the subject of study. According to cognitive sciences, there are two theoretical alternatives to explain categories that are carried out by humans, i.e. categories based on feature similarity and categories based on mental concepts. If feature-based categorization seeks to find natural similarities and differences among categorized entities, then categorization based on concepts sets categories based on mental concepts.

A concept is not just a feature that is stated to exist or not, but as multidimensional criteria which can give birth to a number of simultaneous categorizations for a number of the same entities. A concept also implies a row of rough, vague, and soft categories, rather than hard categories, that is the line between categories is not a clear number or measure, but a perception that is different, in a reasonable sequence, from one person to another.

According to Auda, feature-based categorization was criticized for a number of limitations compared to concept-based categorization. The followings are the theoretical reasons behind the prioritization of concept-based categorization methods rather than feature-based categories, which will be used later, in criticizing the traditional (feature-based) categorization of school of fiqh : Concept-based methods are integrative and systematic methods, unlike feature-based methods, which relate to entities as a list of attributes or unrelated features, thus losing a lot of significant analytical information; Feature-based methods may lead to excessive generalization by summarizing so much information into a simple assessment of the presence or absence of one or more features; Feature-based classification does not provide multi-level ranks or ranks, because it is based on a pigeon hole method which tends to have a simple view between two choices: true/existence or false/non-existence; and to maintain the homogeneity of categorized features, non-binary important factors are sometimes ignored (Auda 2015). 


\section{Towards a Multidimensional Feature}

In the tradition of classical Islamic law, some scholars still use an atomistic, partial, dichotomist, or binary opposition approach between two things to justify a problem. Using this dichotomous approach, various phenomena and ideas appear to contradict one another, such as deductive versus inductive, physical versus metaphysical, material versus of reason, objective versus subjective, religion versus science, empirical versus rational, and so on.

Various phenomena, facts, and ideas are not supposed to be constructed dichotomously so that they are contrary to each other but should be approached in a multi-dimensional manner that can complement each other from different dimensions. The phenomenon of religion and science, for instance, if viewed from a dichotomist perspective or binary opposition, it will appear to contradict each other. But through a multidimensional approach, both are complimentary for the purpose of achieving human happiness, and for the purpose of explaining the origin of life, and so on. Intellect and matter can be seen as contradictory in the dimensions of their relationship with sensual data but can be seen as complementary from the dimensions of cognitive theory or brain sciences and artificial intelligence, and so on (Auda 2015, 92).

Likewise, in resolving conflicts and contradictions between various postulates (dalìl), some scholars still use dichotomous approaches or binary approaches. When there is a conflict between various arguments in one problem, some scholars will use conciliation, deletion, excellence, delay, cancellation, or choose the most compatible with the current conditions. All of these strategies are more likely to be partial, so they do not produce legal products that are contextual with the spirit of the times.

According to Auda, the lack of contextualization of the texts confines fiqh flexibility. For example, eliminating the arguments 
applied in the context of peace for the interests of the arguments applied in the context of war, combined with literal methods, limits the ability of the faqih to deal with these two contexts. When this is combined with rigid and binary methodologies, the final results found are generalizations of laws that are typical of certain situations and conditions to be universal and eternal (Auda 2015, 278-288). The example given by Auda about the approach of the nas in this case is Surah Al-Taubah: 5 which is named ayah al-saif:

"If the Haram months have passed, then kill the polytheists

wherever you find them, and arrest them". (al-Tawbah [9]: 5)

The historical context of this verse, in the 9 of Hijri, is the existence of war between Muslims and the infidels of Mecca. This thematic context (the main language of Surat al-Taubah) is a context of war too. However, this verse is excluded from its thematic and historical context and is claimed to be the law between Muslims and non-Muslims in every place, time, situation and condition. Therefore, the verse is contrary to more than two hundred other verses which call for dialogue, religious freedom, forgiveness, peace, and even patience.

For this reason, multi-dimensional features in Auda's opinion have significance in providing solutions for conflicting postulates. According to Auda, one of the functions of multi-dimensional features, in this case, is to be able to fulfill the best benefit for the community. For this reason, multidimensional features also require pluralistic-style considerations in determining sharia intentions. In this case, the method to elaborate on the contradictions that meet maqāṣid at the highest level must be given priority (Auda 2015, 293).

\section{Towards Intentions}

According to Jasser Auda, the intended features are the most significant part or become a common binder for all other system 
features, such as a feature of cognition, holism, openness, interrelated hierarchies, and morality. Therefore, in the reconstruction of the maqāșid al-shariah paradigm introduced by Jasser Auda, the intentional feature occupies a very important position as the core that directs the main purpose of universal Islamic law.

However, according to Auda, most of studies of classical Islamic law, even in the schools of contemporary legal philosophy, did not include the meaning of intention or maqāsid to recognize Islamic law. According to Auda, this maqāșid generally is considered insufficient ( $\left.q a t^{\prime} i y\right)$ to give legal authority specifically (bujjah). The position of al-Shațibi actually supports maqāșid when explaining al-maqāșid as: "The basis of religion; sharia rules; and the generality of belief". Ibn Ashūr, the leading modernist al-maqāṣid, explained maqāṣid as: "qațiiy or zanniy which is close to qat 'iy". However, so far, theoretically it can be said that maqāsid is still prohibited from playing a leading role in the legal excavation of related texts (Auda 2015, 296-297).

Therefore, it is time to read the fundamental sources of Islamic law and applied holistically. In general, according to Auda, maqāșid's approach really needs to be applied to both the Quran and the Hadith of the Prophet. Regarding maqāṣid recitation of the Quran, Auda suggests to apply thematic methods or maudū' $i$ (Shihab 1997).

Thematic interpretations take a number of steps forward towards the interpretation of the Quran which more considers the maqāsid factor. The method of reading the Quran in relation to the themes, principles, and grand values, stand on the view that the Quran is a holistic-integral. Through thematic interpretations, all the verses of the Quran are an integral among the various verses, both verses about the law and verses about the faith, the stories of the Prophets, the life of the Prophet and the universe. 
This thematic interpretation approach also introduces the principles and values which are the main themes behind the stories in the Quranic and the discussion of the end of the day, which can be 'illat (ratio legis) for the laws, besides 'illat literal which is extracted through traditional methods (takbrij almanat). This will help in the physical stage when 'illat is filtered, as well as in tahqì al-manat when an 'illat is applied in the real world (Auda 2015, 299). Likewise, the maqāṣid-based approach addressed to the traditions of the hadith must depart from a holistic perception (which is similar to the above) to the life and words of the Prophet. This method also should try to describe the complete picture of the Sunnah.

The authenticity of a had tradition which is not coherent with explicit Islamic values is questionable. Ahad traditions, which are questioned based on maqāsid, are the hadith which have systematic incoherence with the holistic system of sharia. Questioning these traditions based on these systematic incoherence criteria differs from the matan's incoherence criteria (shuzīz almatn) in the literature of classical hadith when validating the hadith or weakening a content (tad'if al-matn).

Matan incoherence means that a hadith is contradictory (ta'a $r u d$ ) with several other traditions (with the same or different narrators). If the Jurists cannot reconcile the implications (linguistics) of the two hadiths (or the implications of its 'illat), then the hadith which certainty is lower is considered incoherent. However, systematic incoherence is incoherence with the general principles of Islam, as concluded from a holistic understanding of the texts. Thus, the principle of systematic coherence must be the standard criterion that the Prophet's hadith must be harmonious with the principles of the Quran.

In addition, the maqāșid approach can fill a crucial gap in the history of the hadith, in general, namely the gap that loses 
context. The majority of the hadith of the Prophet in any schools consists of one or two sentences; and the answer to one or two questions, without elaborating the historical, political, economic, and environmental context that surrounds the hadith (Auda 2015, 299-300). Through maqāṣid's approach to the two principal sources in Islam, it may help to understand the objectives of Islamic law.

\section{Maqāṣid al-Shariah Contributions to Contemporary Islamic Renewal}

"Maqāṣid is one of today's most important intellectual means and methodologies for Islamic reform and renewal" (Auda 2008, 22).

The statement above is a quotation from the writings initiated by Jasser Auda about maqāșid al-shariah's contribution in the renewal of contemporary Islamic discourse. According to Auda, maqāṣid al-shariah is one of the most important intellectual and methodological tools today to carry out Islamic reform. Today, there are many voices from outside that suggest for reforming Islamic law. Unfortunately, often these offers are made with unfriendly approaches to Islam and Muslims. Various approaches proposed from outside the intellectual tradition of Islam would instead take the face of Islam and Muslims into an intellectual and social system that are alien to them. It is necessary to renew Islamic law from within the intellectual tradition of Islam itself authentically.

In this context, Auda said "maqāṣid al-shariah could play a positive role in these debates. It is a methodology from 'within' the Islamic scholarship that addresses the Islamic mind and Islamic concerns" (Auda 2008, 23). Because, maqāṣid al-shariah is a methodology originating from an authentic Islamic tradition that is very concerned with Islamic thoughts and Islamic issues. There are a number of positive contributions that maqāșid al-shariah can offer to renew contemporary Islamic law. 
Maqāṣid al-Shariah for Development and Human Rights

The key word used by Jasser Auda in this case is tanmiyah or development, namely the development of the previous concepts of maqāṣid al-shariah not just for protection (hifz). Maqāṣid al-shariah for development and human rights by Auda was developed from an essential benefit (al-daruriyyat) which covers five aspects of protection, namely: (1) Religious protection ( $\mathrm{hifz}$ al-din), (2) Protection of the soul (bifzal-nafs), (3) Protection of reason ( $h i f z a l$-'aql), (4) Protection of offspring and honor (hifz al-nās wa al-ird), and (5) Protection of property (hifz al-māl).

Auda began his study from protection of offspring (hereditary) as one of the main objectives to be achieved by Islamic law. But traditional offspring protection by scholars is still limited to an individual protection. In the $20^{\text {th }}$ century, the writers of al-Maqāșid have enriched the discourse of the protection of offspring is no longer limited to individual, but also social such as family life and social community (Auda 2015, 56).

Similar developments have also been applied to the protection of reason, which until recently has been limited to the wisdom behind the prohibition of alcohol in Islam. This term has developed in the $20^{\text {th }}$ century which included activities in the broadest sense of learning, disseminating scientific discourses, and maintaining the Muslim scientists not to develop their expertise abroad (Auda 2013).

Likewise, with the protection of honor and protection of the soul has undergone a similar development during the journey of al-maqāṣid's knowledge. Initially, these two maqāṣid, by al-Amiri, were placed as the wisdom behind Islamic criminal law which dropped on those who violated honor. After that, al-Juwayni placed them in his protection theory as the protection of honor. Then al-Ghazali and al-Shațibi placed them at the level of necessity (Auda 2013) 
Still in the context of the development of the thinking of maqāsid in the $20^{\text {th }}$ century towards the realization of the development and human rights, discourses maintaining religion embodied the freedom of belief in Ibn Ashūr's perspective, or the freedom to believe, in contemporary expression. Proponents of freedom of belief, in the contemporary meaning, rely on the Quranic verse that says there is no compulsion in religion to be the basic principle.

Proponents of freedom of belief present the verse rather than the concept of hadd al-riddah (apostasy punishment) known in classical fiqh as a punishment for anyone who leaves the religion of Islam, even if he does not commit other crimes, with the aim of preserving religion. Thus, based on the idea of al-maqāșid, any kind of misunderstandings, and politicization of apostasy in Islamic history have been replaced by an original Islamic concept based on the sacred text, namely the concept of religious freedom.

Finally, for the purpose of the development of al-maqāṣid to realize the development and human rights, the term protection of property according to al-Ghazali can be returned to the term protection of property in al-Juwayni's view and the term punishment for theft of al-Amiri; the term also experienced progress towards socio-economic terminology. Preservation of property, in the context of the development of contemporary al-maqāṣid is defined as a kind of social security, economic development, money circulation, public welfare, and reducing inequalities among social classes.

This development enables the use of al-maqāṣid in triggering economic growth, which is very much needed in most of the majority Muslim countries. The development of al-maqāșid's terminology can also provide Islamic alternatives for conventional investment (based on interest/usury); alternatives that have now become quite popular in some developed countries (Auda 2013). 
For this reason, Auda suggested renewing human resources to become one of the main themes for the benefit of the public today. Public benefit for the development of human resources must be one of the main objectives (al-maqāșid) of sharia, which is applied through Islamic law. Thus, linking the development of human resources with al-maqāṣid Islamic law provides a solid foundation in the Islamic world for the realization of the objectives of development, when the goal was radically criticized by a number of (neo)-literalist, as tools of Western domination (Auda 2015, 60). At its peak, as proposed by Jasser Auda, maqāṣid al-shariah must contribute to the widest possible development of human resources.

\section{Maqāșid al-Shariah to Distinguish between Objectives and Means}

The third contribution by Jasser Auda, maqāșid al-shariah is used as an approach that must be able to distinguish between goals and means in understanding and applying Islamic law. To strengthen his argument, Auda shows the views of various Muslim scientists for example: Taha Jabir al-Alwani suggested a reform project on the method of differentiating between means and objectives (Auda 2013). In line with that, Abdul Karim Soroush suggested that sacred texts can be divided into two parts: essential (principle) and accidental (related to changing symptoms of things that are principal). Accidental matters are those that are related to the cultural, social, historical environment of the core message of religion that is to be practiced (Auda 2013).

In his Sharia and Politics work, Jasser Auda revealed a demonstrative example of the Quran regarding the importance of differentiating between means and objectives. Jasser Auda quoted one of the verse in the Quran Surah al-Anfal: 60 (Shihab 2002, 484).

According to him, this verse clearly illustrates the difference between means and purpose. In this verse, Muslims are in- 
structed to prepare themselves in the face of the enemy by using the means of 'moored horses' (ribat al-khail). Although in the verse explicitly stated and textually it is called "horses that are tethered", but in the context of the command the horses are moored only as a means or tool, not as an end in itself. Because the moored horses are only a tool or vehicle, they are contextual, that is, they can change according to conditions, situations, space and time that surrounds them (Auda 2008, 29-30).

Furthermore, if we refer to some contemporary Muslim scholars, they do divide the Islamic doctrine in general into two categories. First, normative-universal texts. This type of Nash is useful and provided as a means to solve problems that might occur in the future, long after the death of Prophet Muhammad and before the end of the world. Likewise this type of text is useful and prepared to answer the challenges and problems that will be faced by human beings from all corners of the world outside Arabia and for all the types of people living in the universe.

Second, practical-temporal texts. This type of Nash is intended to answer the problems and cases of Arab society, especially in the revelation period. This type of Nash can be summed up in the Arabic context. Because this type of text is intended to solve specific problems of the Arab (Abdullah 2002, 250). The classification of Islamic doctrine to normative-universal texts and practical-temporal texts is also a fundamental basis so that we can distinguish between temporal meanings and eternal goals to implement Islamic law.

\section{Maqāṣid al-Shariah for Universal Sharia}

In this context, Jasser Auda proposed 'urf, customs, as one component of Islamic law that can be universal. In general, 'urf means a custom or good habit that can be mutually agreed upon in a community. But in the discourse of usul fiqh, 'urf is juxtaposed with adat, both of which seem to have similar meanings (synonyms) plus different meanings (antonyms). 
With regard to 'urf as a universal component of Islamic law, Jasser Auda adopted the perspective of Ibn Ashūr which outlined a new view of the fundamental role of 'urf based on al-maqāṣid understanding. Ibn Ashūr wrote a chapter in his maqāṣid al-shariah concerning ' $u r f$, where he occupied the discussion in the context of achieving the aim/purpose of 'universality of Islamic law' (Islamic law as a global religious rule/having a solution for all problems in all contexts).

In this chapter, Ibn Ashūr does not confine himself to the discussion of the influence of ' $u r f$ in the application of the sacred texts which is a classic discussion in fiqh. But he discusses the influence of 'urf on the texts themselves (Auda 2013). Ibn Ashūr explained that it was important for Islamic law to be a universal law because it is supposed to be applied for all human beings on earth (Auda 2015, 312). Even Ibn Ashūr asserted: "It is very applicable to all of the worlds up to the end of the world, Islamic legal rules must be applied to all human beings anywhere in the world until the end" (Ibn Ashūr 2006).

\section{Conclusion}

From the various expositions that have been explored above, some conclusions can be made as follows. First, the construction of the paradigm of the classic maqāsid al-shariah is still more individual. The classic maqāṣid al-shariah paradigm makes three maqāṣid al-shariah typologies that include categories: darūriyyāt (essential), hājiyyāt (complimentary), and häjiyyāt (tertiary). These three typologies are sequences that are still maintained in maintaining the significance as well as relevance of darūriyyāt, häjiyyāt, and tabsiniyyāt. In the essential part, classical maqāṣid al-sharia experts also chronologize in five aspects in a sequential category which starts from preserving religion ( $h i f z$ al-dinn), nurturing the soul (bifz al-nafs), nurturing the mind (bifz al-'aql), maintaining descent ( $h i f z$ an-nasl), and preserving property (hifz $a l-m \bar{a} l)$. 
Second, the reconstruction of maqāṣid al-shariah constructed by Jasser Auda uses the approach of system philosophy. The philosophical approach of the system views the world and the functions of nature and all its components in the context of a holistic system that is composed of infinite sub-systems which have an interaction, open, hierarchical and purposeful natures. The philosophical approach of the reconstructed Islamic system by Auda proposes a series of new system features that can be used in systematic analysis for maqāṣid al-shariah which includes six features including cognitive nature of the system, wholeness, openness, interrelated hierarchy, multidimensionality, and purposefulness.

Third, the maqāṣid al-shariah reconstruction initiated by Jasser Auda offers three positive contributions to the development of Islamic law i.e. maqāṣid al-shariah for development and human rights, to distinguish between objectives and means, and for universal sharia footing.

\section{Bibliography}

Abdullah, M. Amin. 2002. Mazhab Jogia: Menggagas Paradigma Ushul Fiqh Kontemporer. Yogyakarta: Ar-Ruzz Media. . 2012. "Bangunan Baru Epistemologi Keilmuan Studi Hukum Islam Dalam Merespon Globalisasi”,.” Jurnal Ilmu Syariah Dan Hukum 46 (II): 315-68.

Al-Alwani, Taha Jabir. 2001. Maqāṣid Al-Sharia. Beirut: IIIT \& Dar al-Hadi.

Auda, Jasser. 2008a. Maqāṣid Al-Shari'ah: A Beginner's Guide. London: The International Institute of Islamic Thought. . 2008b. Maqāṣid Al-Shariah as Philosophy of Islamic Law. London: The International Institute of Islamic Thought.

- 2008c. Sharia and Politics. London: The International Institute of Islamic Thought. 
- 2013. Al-Maqāṣid Untuk Pemula. Edited by Ali Abd ElMun'im. Yogyakarta: SUKA Press.

- 2015. Membumikan Hukum Islam Melalui Maqāṣid Syariah. Edited by Rosidin and Ali Abd El-Mun'im. Bandung: Mizan.

Busyro. 2017. Maqāṣid Al-Syariah. Ponorogo: Wade Group.

Ibn Ashūr, Muhammad Al-Ṭahir. 2006. Treatise on Maqāṣid Al-Shariah. London: The International Institute of Islamic Thought.

Kamali, Mohammad Hasim. 2008. Membumikan Syariah. Edited by Miki Salman. Bandung: Mizan.

Marcoes, Lies. 2018. Maqāṣid Al-Islam. Jakarta: Yayasan Rumah Kitab.

Mawardi, Ahmad Imam. 2010. Fiqh Minoritas. Yogyakarta: LKiS.

Mu'ammar, M. Arfan and Abdul Wahid Hasan (ed.). 2012. Studi Islam. Yogyakarta: IRCISOD.

Riḍa, Muhammad Rashid. 1406. Al-Wahy Al-Muhammadiy. Cairo: Mu'assas 'Izz al-Din.

Sahabuddin (ed.). 2007. Ensiklopedi Al-Qur'an. Jakarta: Lentera Hati.

Shihab, M. Quraish. 1997. Wawasan Al-Qur'an. Bandung: Mizan.

_. 2002. Tafsir Al-Misbah Vol. 5. Jakarta: Lentera Hati.

Subhan, Muhammad. 2013. Tafsir Maqāṣidiy. Kediri: Lirboyo Press. 